\title{
O estado laico na atualidade: uma análise comparativa da laicidade nos ordenamentos jurídicos brasileiro e espanhol
}

\section{Laico state: a comparative analysis of secularity in the brazilian and spanish legal systems}

Renata de Assis Calsing(1); Julio Estron Santos(2); Carolina Costa Santos(3)

1 Professora Titular do Curso de Direito do UDF. Doutora em Direito pela Universidade de Paris I, Panthéon-Sorbonne. Professora Associada do PPGD do UniCEUB. Analista de Finanças e Controle da Controladoria Geral da União.

E-mail: renata.calsing@gmail.com

2 Professor dos cursos de graduação em Direito e Relações Internacionais e especialização da UCB/DF. Doutorando em Direito pelo UniCEUB.

E-mail: edstron@yahoo.com.br

3 Graduada em História pela UNB e Direito pela Universidade Católica de Brasília.

E-mail: carolina.costa@catolica.edu.br

Revista Brasileira de Direito, Passo Fundo, vol. 13, n. 2, p. 357-388, Mai.-Ago. 2017 - ISSN 2238-0604

[Recebido: Abr. 06, 2016; Aprovado: Dez. 28, 2016]

DOI: http://dx.doi.org/10.18256/2238-0604/revistadedireito.v13n2p357-388

Como citar este artigo / How to cite item: clique aqui! / click here! 


\title{
Resumo
}

O presente artigo consiste em uma análise comparativa da laicidade nos ordenamentos jurídicos brasileiro e espanhol. Primeiramente, busca-se uma construção do conceito de laicidade. Em seguida, realiza-se uma abordagem do processo histórico brasileiro e espanhol, verificando-se o desenvolvimento da laicidade nestes Estados, bem como esta se apresenta em seus sistemas jurídicos. Por fim, procura-se realizar uma análise comparativa da laicidade nos ordenamentos jurídicos do Brasil e da Espanha, buscando-se verificar os pontos de convergência e de divergência encontrados no Estado laico dos referidos países.

Palavras-chave: Laicidade. Estado Laico. Direito Comparado. Brasil. Espanha.

\begin{abstract}
This article consists of a comparative analysis of secularism in the Brazilian and Spanish legal systems. First, we seek a construction of the concept of secularism. It then performs an approach the Brazilian and Spanish historical process, verifying the development of secularism in these states, and it is presented in their legal systems. Finally, it seeks to carry out a comparative analysis of secularism in the legal systems of Brazil and Spain, seeking to verify the points of convergence and divergence found in the secular state of these countries.
\end{abstract}

Keywords: Secularism. Secular State. Comparative law. Brazil. Spain. 


\section{Introdução}

Existe, atualmente, bastante discussão acerca da laicidade do Estado, tanto no Brasil quanto em outros países, amplificada pelo fluxo migratório e o grande número de refugiados que chega a Europa.

Preliminarmente, se deve destacar que a laicidade consiste na neutralidade e na não a assunção de tarefas religiosas pelo Estado, sem impedir, contudo, o reconhecimento do papel da religião e dos diversos cultos existentes na sociedade.

Nota-se que a crescente valorização da liberdade de consciência, de crença e de não crença exige uma postura de imparcialidade do Estado em relação a todas as manifestações religiosas ou não religiosas, cabendo a este, portanto, manter sua laicidade.

Para o estudo do Estado laico brasileiro, pretende-se fazer uma comparação com a laicidade no Estado espanhol, porquanto se trata de país que exerceu enorme influência política e cultural no Brasil, desde os tempos coloniais, e continua exercendo, a despeito de não ser o único a exercê-la nos dias de hoje.

A análise do Estado laico nos países mencionados será feita a partir da utilização do Direito Comparado, sendo este compreendido como o ramo da ciência jurídica que estuda as diferenças e as semelhanças entre os ordenamentos jurídicos de diferentes Estados.

Assim, a problematização abordada neste artigo é buscar saber qual (is) é (são) a (s) diferença (s) e a (s) semelhança (s) da laicidade nos ordenamentos jurídicos dos Estados brasileiro e espanhol.

A questão da laicidade possui grande importância no atual contexto de nossa sociedade, ainda mais se considerarmos a recorrente discussão que se observa acerca de temas em que a religiosidade possui influência em vários setores, inclusive, na política brasileira, já que a bancada denomina "evangélica” é a que mais cresce no Congresso Nacional.

Pode-se dizer que o problema do relacionamento entre religião e política, ou entre Igreja e Estado, é questão fundamental de uma sociedade livre, na medida em que se apresenta a possibilidade de os membros de uma coletividade terem a liberdade de pensar o que querem e de expressarem, sem constrangimento, o que pensam.

Observe-se que não se pretende com isso diminuir a importância das manifestações religiosas na comunidade, mas tão somente separar a influência da religião na política brasileira nos moldes em que se encontra hodiernamente, sobretudo porque a proposta de nossa Constituição é pela existência de um Estado verdadeiramente laico.

Ressalte-se que a liberdade religiosa é direito constitucional a ser defendido, porquanto se verifica que é cada vez mais difícil exercer de forma livre e pacífica qualquer manifestação de religiosidade sem sofrer alguma espécie de represália por isso, tais como preconceitos, dentre outros. 
De outro modo, não se pode olvidar que, atualmente, o Estado brasileiro é laico, nos moldes constitucionais tal como demonstra o artigo $5^{\circ}$, VI, não devendo tomar partido para defender nenhuma religião em particular, mas, ao contrário, defender que a atuação política estatal não deve se imiscuir em assuntos religiosos (e vice-versa), assim como proteger todas as formas de religiosidade sem distinções.

O presente artigo possui como objetivo averiguar a questão da laicidade do Estado, buscando-se estabelecer uma abordagem comparativa entre a laicidade nos moldes em que se apresenta nos sistemas jurídicos do Brasil e da Espanha. Para tanto, o artigo será estruturado da seguinte maneira.

Em primeiro lugar, o estudo abordará a construção do conceito de laicidade. Posteriormente, apresentam-se aspectos históricos do Brasil e da Espanha. Ainda, será demonstrada como a laicidade se apresenta no ordenamento jurídico brasileiro e espanhol. E, por fim, realizar-se-á a análise comparativa dos referidos sistemas jurídicos.

Espera-se que o estudo em comento possa contribuir de alguma forma para o incremento do conhecimento acerca do assunto, assim como para o aumento do debate sobre a laicidade do Estado, sua importância e sua observância na sociedade atual.

\section{Construção do conceito de laicidade}

No que concerne à relação entre o fenômeno religioso e o Estado, o professor português Jorge Miranda aduz que o fenômeno religioso possui importante projeção política e jurídica, uma vez que penetra na esfera mais íntima da consciência humana, manifestando-se em grandes movimentos coletivos. Para o autor, tal fenômeno exerce influência permanente tanto na história cultural quanto na história política, de modo que "nenhuma Constituição deixa de o considerar e repercute-se ainda no Direito internacional" (MIRANDA, 2013, p. 21).

Não obstante, o fenômeno religioso apresenta-se das mais variadas formas, de acordo com a época e o lugar, o Estado e o regime político adotado, sua relevância social, bem como a relação entre o poder público e as confissões religiosas. Disso decorre que não existe um modelo único de laicidade, tendo em vista a própria diversidade de religiões, assim como o posicionamento estatal diante destas.

O Dicionário de Política, organizado por Norberto Bobbio, apresenta o vocábulo "laicismo", definido por Valerio Zanone, a partir de dois significados. O primeiro deles trata da cultura leiga, relacionando-se ao movimento cultural da Renascença - movimento que gerou uma separação paulatina entre o pensamento político e o religioso, com sua origem fundamentada, sobretudo, no racionalismo. Já o segundo significado refere-se ao Estado laico propriamente dito, conforme adiante transcrito: 
[...] O Estado leigo é oposto do Estado confessional, ou seja, é o oposto de um Estado que assume para si determinada religião e privilegia os fiéis desta em relação aos fiéis de outras religiões e aos não crentes. Assim, Estado laico é um Estado não clerical, conforme as correntes políticas que defendem a autonomia de instituições públicas e da sociedade civil das diretrizes emanadas pelo magistério eclesiástico e de interferência de organizações confessionais. Um regime em que vigora a separação entre o Estado e a Igreja. Cabe destacar que o Estado laico não é um Estado irreligioso, mas apenas não confessional, o que significa dizer que ele é separado de confissões religiosas, mas deve garantir a liberdade de religião e de culto a todos os grupos religiosos, sem implementar privilégios nem estruturas de controle direcionadas a certas confissões, salvaguardando assim a autonomia do poder civil de eventual tentativa de controle religioso e, simultaneamente, defendendo as confissões de qualquer tentativa de restrição ao livre exercício de culto por parte do poder temporal (ZANONE, 2004, p. 670).

A despeito da utilização da terminologia laicismo como se fosse laicidade, é preciso destacar que alguns autores não utilizam tais conceitos como se sinônimos fossem. Isto é, quando vigora no Estado o laicismo, é atribuído um juízo de valor negativo ao fenômeno religioso; diferentemente da laicidade, em que o que ocorre é somente uma isenção estatal em relação aos variados grupos religiosos.

Ainda segundo a doutrina portuguesa existe uma diferença entre laicidade e laicismo, a saber:

Laicidade significa não assunção de tarefas religiosas pelo Estado e neutralidade, sem impedir o reconhecimento do papel da religião e dos diversos cultos. Laicismo significa desconfiança ou repúdio da religião como expressão comunitária e, porque imbuído de pressupostos filosóficos ou ideológicos (o positivismo, o cientismo, o livre pensamento ou outros), acaba por pôr em causa o próprio princípio da laicidade. [...] (MIRANDA, 2013, p. 28).

De acordo com João Vianney Cavalcanti Nuto e Pedro Ivo Souza de Alcântara, "laicidade estatal é a emancipação recíproca entre Estado e religiões, para que se permita o livre exercício religioso, efetivando-se, outrossim, direitos individuais de liberdade do cidadão em relação a sua crença e culto”. (NUTO; ALCÂNTARA, 2014, p. 109).

De maneira didática, o magistrado William Douglas apresenta as seguintes definições: 
A - Laico, onde todas as manifestações religiosas, incluindo o ateísmo, o ceticismo e o agnosticismo são respeitadas, sem que o Estado privilegie nenhuma religião nem dificulte seu exercício (vide art. 19, CF).

B - Confessional, onde um modo de ver a religião é acolhido em detrimento dos demais. Aqui, temos Estados confessionais católicos, islâmicos, protestantes ou ateus, entre outros. (DOUGLAS, 2015, p. 3).

Já conforme Lacerda, a definição da laicidade caracteriza-se pelo fato de o Estado não possuir nenhuma doutrina oficial, uma vez que não pode professar ou favorecer nenhuma religião, conforme o que se segue:

A idéia básica da laicidade é bastante simples: grosso modo, ela consiste em que o Estado não professa nem favorece (nem pode professar ou favorecer) nenhuma religião; dessa forma, ela contrapõe-se ao Estado confessional - em que se inclui o assim chamado "Estado ateu", considerando que este assume uma posição caracteristicamente religiosa, mesmo que seja em um sentido negativo. Desta forma, seguindo a laicidade, o Estado não possui doutrina oficial, tendo como consequências adicionais que os cidadãos não precisam filiar-se a igrejas ou associações para terem o status de cidadãos e inexiste o crime de heresia (ou seja, de doutrinas e/ou interpretações discordantes e/ou contrárias à doutrina e à interpretação oficial). (LACERDA, 2014, p. 181).

Destaque-se que cada ordenamento jurídico possui um modelo de laicidade estatal diferente, conforme já mencionado, sendo que em alguns há uma aproximação maior entre religiões e o poder temporal e em outros a aproximação é menor.

Nos países em que existe uma grande divisão religiosa, ocorre geralmente um regime de separação absoluta, a exemplo do que ocorreu na França. Já nos países com religião maioritária e com fundo histórico, muitas vezes adota-se tratamento preferencial ou até mesmo privilegiado dessa religião, sem haver, contudo, prejuízo da liberdade religiosa, como ocorre no Brasil, em Portugal e na Espanha, por exemplo.

Nesse sentido, Jorge Miranda esclarece que a:

[...] separação não determina necessariamente desconhecimento da realidade social e cultural religiosa, nem relegar as confissões religiosas para a esfera privada. A existência das confissões e das suas atividades não pode ser ignorada ou secundarizada e nada impede mesmo que se firmem laços de cooperação delas com o Estado em diversos domínios. (MIRANDA, 2013, p. 27). 
Blancarte define a laicidade como "um regime social de convivência, cujas instituições políticas estão legitimadas principalmente pela soberania popular e já não mais por elementos religiosos" (BLANCARTE, 2008, p. 19). Segundo o autor, a democracia e a laicidade estão intimamente relacionadas. Para ele,

\begin{abstract}
A definição anterior de laicidade, centralizada na idéia da transição entre uma legitimidade outorgada pelo sagrado e uma forma de autoridade proveniente do povo, permite-nos entender que a laicidade - como a democracia - é mais um processo do que uma forma fixa ou acabada em forma definitiva. Da mesma maneira que não se pode afirmar a existência de uma sociedade absolutamente democrática, tampouco existe na realidade um sistema político que seja total e definitivamente laico. (BLANCARTE, 2008, p. 20).
\end{abstract}

Isto é, a despeito da tentativa de se chegar a um conceito único e acabado, deve-se compreender a laicidade como um processo em constante transformação, sendo que cada Estado será mais ou menos laico, conforme tenha ou não, e em que grau, relação de interdependência com alguma instituição religiosa ou confissão.

Ressalte-se, ainda, que laico não significa o contrário de religioso. Nesse sentido, Blancarte esclarece que:

O Estado laico não deve ser entendido como uma instituição antireligiosa ou anticlerical, mesmo que em diversos momentos de sua construção histórica o tenha sido. O Estado laico é a primeira organização política que garantiu as liberdades religiosas, como a liberdade de crenças e a liberdade de culto. (BLANCARTE, 2008, p. 31).

Do exposto, decorre que várias são as questões que envolvem a construção do conceito de laicidade.

\title{
3 Aspectos históricos do Brasil
}

Tendo em vista que o Brasil iniciou a sua história conhecida e documentada praticamente a partir da colonização portuguesa, é necessário destacar que a laicidade brasileira deve ser analisada, então, a partir deste momento.

Os atos públicos de Portugal estavam vinculados à Igreja Católica Apostólica Romana, tendo o Brasil surgido como colônia de um Estado confessional. Dessa forma, havia correlação entre a Coroa portuguesa e Igreja Católica na exploração do Brasil, momento em que inexistia laicidade no país. 
Assim, a colonização do Brasil se iniciou sob o símbolo da cruz católica, evidenciando-se uma ligação com uma confissão específica. Logo, o Brasil Colônia, o Reinado e, posteriormente, o Brasil Imperial foram expressões de Estado Confessional, sendo que apenas com o Brasil República é que surgiu a opção pela laicidade, em decorrência de uma série de mudanças ocorridas na cultura ocidental.

Convém falar que a realidade política brasileira possuiu um aspecto particular, uma vez que a Independência do Brasil, em 1822, não foi responsável pela criação de uma identidade de unidade nacional, conquanto não tenha nascido de uma batalha entre portugueses e brasileiros.

Saliente-se que não apenas os grupos conservadores, como também os liberais, eram contrários a uma efetiva transformação estrutural e política do país, de modo que evitaram a todo custo abraçar projetos mais ambiciosos, como o da separação entre Igreja e Estado.

Desse modo, tanto no decorrer do período colonial (1500-1822), quanto no curso do contexto imperial (1822-1889), não houve, de fato, liberdade religiosa no Brasil, sendo esta compreendida como a livre expressão pública da religião, já que o catolicismo era a única religião legalmente aceita. A Constituição do Império representou um avanço mínimo, pois, apesar de permitir o culto doméstico das demais religiões, determinava a religião católica como oficial, conforme se verifica em seu Art. $5^{\circ}$, in verbis:
A Religião Catholica Apostolica Romana continuará a ser a Religião do Império. Todas as outras Religiões serão permitidas com seu culto domestico, ou particular em casas para isso destinadas, sem fórma alguma exterior do Templo. (BRASIL, 2015, p. 1).

Tratava-se, então, de um Estado Confessional. O Art. 103 da referida Constituição demonstra a função religiosa do Imperador, nitidamente vinculada ao sacerdócio católico, a seguir transcrito:
O Imperador antes de ser aclamado prestará nas mãos do Presidente do Senado, reunidas as duas Camaras, o seguinte Juramento - Juro manter a Religião Catholica Apostolica Romana, a integridade, e a indivisibilidade do Imperio; observar, e fazer observar a Constituição Politica da Nação Brazileira, e mais Leis do Imperio, e prover ao bem geral do Brazil, quanto em mim couber. (BRASIL, 2015, p. 10).

Todavia, as relações entre Igreja e Estado apresentavam contradições. Se, de um lado, o catolicismo gozava de privilégios com o regime do padroado; por outro lado, o catolicismo se submetia ao Estado, e por ele era tutelado. 
Nesse sentido, a fraqueza da Igreja Católica nacional ao longo do século XIX encontra explicação nos séculos de padroado sobre a Igreja colonial, que, controlada pelo Estado, teve sua dependência aumentada, tornando grande parte do clero subserviente ao governo, em troca de cargos públicos.

Dessa forma, a primeira metade do século XIX, no Brasil, foi marcada por conflitos, ocorridos entre o Estado confessional católico e outros grupos religiosos e entre o Estado brasileiro e a Santa Sé. Somente com a chegada da República, o governo provisório começou a instaurar a definitiva separação entre Estado e religião.

A primeira Constituição republicana, de 1891, tornou oficial, em seu art. 72, a separação entre Igreja e Estado no Brasil, pois extinguiu o monopólio católico ao secularizar os aparelhos estatais ligados à criação do casamento e aos cemitérios leigos, conforme se verifica no dispositivo citado a seguir:

\section{[...]}

$\S 3^{\circ}$ Todos os individuos e confissões religiosas podem exercer publica e livremente o seu culto, associando-se para esse fim e adquirindo bens, observadas as disposições do direito commum. $\S 4^{\circ}$ A Republica só reconhece o casamento civil, cuja celebração será gratuita.

$\$ 5^{\circ}$ Os cemiterios terão caracter secular e serão administrados pela autoridade municipal, ficando livre a todos os cultos religiosos a pratica dos respectivos ritos em relação aos seus crentes, desde que não offendam a moral publica e as leis.

$\$ 6^{\circ}$ Será leigo o ensino ministrado nos estabelecimentos publicos. $\$ 7^{\circ}$ Nenhum culto ou igreja gosará de subvenção official, nem terá relações de dependencia ou alliança com o Governo da União, ou o dos Estados. A representação diplomatica do Brasil junto á Santa Sé não implica violação deste principio. (BRASIL, 2015, p. 18).

Em decorrência do contexto histórico mundial, assim como da conjuntura de crise vivida pelo país, o Brasil aboliu o padroado, com a proclamação da República Federativa do Brasil, em 1889, determinando a separação entre e Igreja e Estado.

Nesse sentido, o decreto 119-A, de 7 de janeiro de 1890, escrito por Ruy Barbosa e expedido pelo Governo Provisório, estabeleceu, do ponto de vista jurídico, a referida separação, proibindo a intervenção da autoridade federal e dos Estados federados em matéria religiosa, consagrando a plena liberdade de cultos, extinguindo o padroado e estabelecendo outras providências, conforme abaixo transcrito:

Art. $1^{\circ}$ E’ prohibido á autoridade federal, assim como á dos Estados federados, expedir leis, regulamentos, ou actos administrativos, estabelecendo alguma religião, ou vedando-a, e crear differenças entre os habitantes do paiz, ou nos serviços sustentados á custa do 
orçamento, por motivo de crenças, ou opiniões philosophicas ou religiosas.

Art. $2^{\circ}$ a todas as confissões religiosas pertence por igual a faculdade de exercerem o seu culto, regerem-se segundo a sua fé e não serem contrariadas nos actos particulares ou publicos, que interessem o exercicio deste decreto.

Art. $3^{\circ}$ A liberdade aqui instituida abrange não só os individuos nos actos individuaes, sinão tabem as igrejas, associações e institutos em que se acharem agremiados; cabendo a todos o pleno direito de se constituirem e viverem collectivamente, segundo o seu credo e a sua disciplina, sem intervenção do poder publico.

Art. $4^{\circ}$ Fica extincto o padroado com todas as suas instituições, recursos e prerogativas.

Art. $5^{\circ} \mathrm{A}$ todas as igrejas e confissões religiosas se reconhece a personalidade juridica, para adquirirem bens e os administrarem, sob os limites postos pelas leis concernentes á propriedade de mãomorta, mantendo-se a cada uma o dominio de seus haveres actuaes, bem como dos seus edificios de culto.

Art. $6^{\circ}$ O Governo Federal continúa a prover á congrua, sustentação dos actuaes serventuarios do culto catholico e subvencionará por anno as cadeiras dos seminarios; ficando livre a cada Estado o arbitrio de manter os futuros ministros desse ou de outro culto, sem contravenção do disposto nos artigos antecedentes.

Art. $7^{\circ}$ Revogam-se as disposições em contrario. (BRASIL, 2015, p. 1).

Destaque-se que o Decreto n 119-A objetivava a emancipação recíproca da Igreja e do Estado, de modo que ambas as instituições pudessem auferir o benefício mútuo da liberdade, bem como garantir a tolerância e a liberdade de convicção dos cidadãos. Assim, com a $1^{\text {a }}$ Constituição da República brasileira e com o decreto acima mencionado, estava instituída juridicamente, em termos, a laicidade no Brasil.

\section{Laicidade no ordenamento jurídico brasileiro}

As liberdades de consciência e de religião foram reconhecidas na Constituição de 1988. No entanto, ainda que possuam pontos de convergência em vários aspectos, não se confundem entre si.

A liberdade de consciência não se resume ao aspecto religioso, porém nele encontra expressão relevante. Está prevista no art. 5 , VI e VIII, da Constituição, conforme se verifica na transcrição do texto constitucional abaixo:

Art. $5^{\circ}$ Todos são iguais perante a lei, sem distinção de qualquer natureza, garantindo-se aos brasileiros e aos estrangeiros residentes 
no País a inviolabilidade do direito à vida, à liberdade, à igualdade, à segurança e à propriedade, nos termos seguintes:

$[\ldots]$

VI - é inviolável a liberdade de consciência e de crença, sendo assegurado o livre exercício dos cultos religiosos e garantida, na forma da lei, a proteção aos locais de culto e a suas liturgias;

$[\ldots]$

VIII - ninguém será privado de direitos por motivo de crença religiosa ou de convicção filosófica ou política, salvo se as invocar para eximir-se de obrigação legal a todos imposta e recusar-se a cumprir prestação alternativa, fixada em lei; (BRASIL, 2015, p. 2).

Existe, no texto constitucional, a previsão de caso expresso de objeção de consciência no art. $143, \S 1^{\circ}$, in verbis:

Art. 143. O serviço militar é obrigatório nos termos da lei.

$\$ 1^{\circ}$ Às Forças Armadas compete, na forma da lei, atribuir serviço alternativo aos que, em tempo de paz, após alistados, alegarem imperativo de consciência, entendendo-se como tal o decorrente de crença religiosa e de convicção filosófica ou política, para se eximirem de atividades de caráter essencialmente militar. (BRASIL, 2015, p. 54).

De acordo com o magistério de Gilmar Ferreira Mendes e Paulo Gustavo Gonet Branco, não é cabível ao Estado interferir na esfera íntima do indivíduo, conforme se verifica no trecho a seguir exposto:

A liberdade de consciência ou de pensamento tem que ver com a faculdade de o indivíduo formular juízos e ideias sobre si mesmo e sobre o meio externo que o circunda. O Estado não pode interferir nessa esfera íntima do indivíduo, não lhe cabendo impor concepções filosóficas aos cidadãos. Deve, por outro lado - eis um aspecto positivo dessa liberdade -, propiciar meios efetivos de formação autônoma da consciência das pessoas.

Se o Estado reconhece a inviolabilidade da liberdade de consciência deve admitir, igualmente, que o indivíduo aja de acordo com as suas convicções. Haverá casos, porém, em que o Estado impõe conduta ao indivíduo que desafia o sistema de vida que as suas convicções construíram. Cogita-se, então, da possibilidade de reconhecer efeitos a uma objeção de consciência. (MENDES; BRANCO, 2011, p. 352).

Também cabe destacar que o Supremo Tribunal Federal assim sentenciou na ADPF 54: "O Brasil é uma república laica, surgindo absolutamente neutro quanto às religiões.”, demonstrando a posição jurídica atual do Brasil sobre este tema. 
Um importante exemplo de objeção de consciência ocorre em relação às transfusões de sangue em testemunhas de Jeová. No entanto, neste caso, a tendência é não aceitar a escusa. Consistem, ainda, em exemplos de escusa de consciência: o dever de alistamento eleitoral aos maiores de 18 anos e o dever de voto aos maiores de 18 anos e menores de 70 anos e a obrigatoriedade do Júri.

Dessa forma, a objeção de consciência representa o respeito à intimidade e à consciência do indivíduo por parte do Estado, estabelecido de forma harmônica entre o direito que o Estado possui de impor suas normas e o direito que o indivíduo tem de viver conforme os valores por ele escolhidos, em face da liberdade de consciência. Ressalte-se que, neste caso, torna-se necessário fazer um juízo de ponderação.

Já na liberdade religiosa estão incluídas a liberdade de crença, de adesão a alguma religião e a liberdade de exercício do respectivo culto, de maneira que os locais de culto e as liturgias são protegidos nos termos da lei. Os locais públicos não são, por essência, locais de culto, mas podem ocorrer manifestações religiosas, desde que respeitados os limites impostos ao direito de reunião constitucionalmente estabelecido. Inclui-se também na liberdade de religião, a liberdade de organização religiosa, não podendo o Estado interferir acerca da economia interna das associações religiosas.

Questão fundamental diz respeito à imunidade tributária dos templos religiosos. Nesse sentido, Mendes e Branco destacam que o constituinte estabeleceu a imunidade de impostos sobre templos de qualquer culto no art. 150, VI, alínea $b$, da Constituição de 1988, com a finalidade de se evitar que o Estado crie embaraços à liberdade de religião. (MENDES; BRANCO, 2011, p. 357).

Nesse diapasão, nota-se que o Estado brasileiro não é confessional, porém, tampouco é ateu, conforme se infere do preâmbulo do texto constitucional, o qual invoca a Deus. Desse modo, permite-se o ensino religioso em escola pública, mesmo que seja como disciplina de matrícula facultativa, nos moldes do art. $210, \S 1^{\circ}$, da CF:

\footnotetext{
Art. 210. Serão fixados conteúdos mínimos para o ensino fundamental, de maneira a assegurar formação básica comum e respeito aos valores culturais e artísticos, nacionais e regionais. $\$ 1^{\circ} \mathrm{O}$ ensino religioso, de matrícula facultativa, constituirá disciplina dos horários normais das escolas públicas de ensino fundamental. (BRASIL, 2015, p. 77).
}

O entendimento de Alexandre Moraes é de que essa previsão constitucional deve se adequar "às demais liberdades públicas, dentre elas a liberdade de culto religioso e a previsão do Brasil como um Estado laico", verificando-se uma dupla garantia constitucional. (MORAES, 2012, p. 49). O autor ensina que: 
Primeiramente, não se poderá instituir nas escolas públicas o ensino religioso de uma única religião, nem tampouco pretenderse doutrinar os alunos a essa ou àquela fé. A norma constitucional pretende, implicitamente, que o ensino religioso deverá constituirse de regras gerais sobre religião e princípios básicos da fé. Em segundo lugar, a Constituição garante a liberdade das pessoas em matricularem-se ou não, uma vez que, conforme já salientado, a plena liberdade religiosa consiste também na liberdade ao ateísmo. (MORAES, 2012, p. 49).

Admite-se, ainda, que o casamento religioso produza efeitos civis, a teor do art. $226, \$ \$ 1^{\circ}$ e $2^{\circ}$, da CF, conforme segue-se:

Art. 226. A família, base da sociedade, tem especial proteção do Estado.

$\$ 1^{\circ} \mathrm{O}$ casamento é civil e gratuita a celebração.

$\$ 2^{\circ} \mathrm{O}$ casamento religioso tem efeito civil, nos termos da lei.

(BRASIL, 2015, p. 82).

Igualmente, a liberdade religiosa apresenta-se sob a forma de prestação, assegurando o art. $5^{\circ}$, VII, da CF, a prestação de assistência religiosa nas entidades civis e militares de internação coletiva, nos termos da lei. Assim, não cabe ao Estado impor aos internos dessas entidades o atendimento a serviços religiosos, mas sim colocar à disposição o conforto religioso àqueles que o anseiam.

A despeito da garantia constitucional prevista no art. 5º, VII, supracitado, existem doutrinadores que criticam o referido dispositivo, alegando sua incompatibilidade com o Estado laico. Todavia, Moraes assevera que:

Não nos parece procedente a crítica que alguns doutrinadores fazem a esse inciso da Constituição Federal, afirmando que não há compatibilidade entre um Estado laico e a previsão, como direito individual, de prestação de assistência religiosa, uma vez que o Estado brasileiro, embora laico, não é ateu, como comprova o preâmbulo constitucional, e, além disso, trata-se de um direito subjetivo e não de uma obrigação, preservando-se, assim, a plena liberdade religiosa daqueles que não professam nenhuma crença. (MORAES, 2012, p. 49-50).

Em complemento e em consonância com o ensinamento acima exposto, Mendes e Branco preceituam que: 


\begin{abstract}
A laicidade do Estado não significa, por certo, inimizade com a fé. Não impede a colaboração com confissões religiosas, para o interesse público (CF, art. 19, I). A sistemática constitucional acolhe, mesmo, expressamente, medidas de ação conjunta dos Poderes Públicos com denominações religiosas e reconhece como oficiais certos atos praticados no âmbito de cultos religiosos, como é o caso da extensão dos efeitos civis ao casamento religioso. (MENDES; BRANCO, 2011, p. 359).
\end{abstract}

Dessa maneira, a celebração de concordata com a Santa Sé consiste em uma iniciativa positiva, considerando que a Igreja tem a finalidade religiosa de propiciar o bem integral do indivíduo, em total consonância com o objetivo da República de promover o bem de todos (art. 3º, IV, da Constituição da República Federativa do Brasil de 1988).

Contudo, não se pode confundir tal modalidade de acordo com a vedação imposta no art. 19, I, da Constituição, na medida em que a aliança que se pretende afastar é aquela que obstaculiza a própria liberdade de crença preconizada no art. $5^{\circ}$, VI, da CF, uma vez que impede a atuação livre de outras confissões religiosas no país. Cabe citar o inteiro teor do dispositivo mencionado:

\footnotetext{
Art. 19. É vedado à União, aos Estados, ao Distrito Federal e aos Municípios:

I - estabelecer cultos religiosos ou igrejas, subvencioná-los, embaraçar-lhes o funcionamento ou manter com eles ou seus representantes relações de dependência ou aliança, ressalvada, na forma da lei, a colaboração de interesse público; (BRASIL, 2015, p. 9).
}

Aduz ainda Moraes que "a conquista constitucional da liberdade religiosa é verdadeira consagração de maturidade de um povo”. (MORAES, 2012, p. 46). Por isso, a proteção à liberdade de religião constante na atual Constituição tem por objetivo facilitar que as pessoas possam viver a sua fé.

Ademais, o texto constitucional assegura a liberdade de crença, porquanto toma a religião como um bem valioso por si mesmo, tendo em vista, sobretudo, sua influência para a formação do caráter cultural e histórico de um povo. Todavia, a questão religiosa não se esgota nos exemplos acima mencionados, encontrando ainda muitas manifestações na sociedade, gerando, por vezes, conflitos complexos que necessitam ser solucionados.

Atualmente, são muitas as demandas que chegam rotineiramente ao Poder Judiciário sobre o alcance do Estado laico brasileiro. Uma dessas questões trata-se da utilização de crucifixos e demais símbolos religiosos presentes em órgãos públicos, 
havendo posicionamento jurisprudencial em ambos os sentidos. Nessa perspectiva, confira-se a seguinte ementa, cuja relatoria do voto foi realizada pelo Desembargador Cláudio Baldino Maciel:

\section{EXPEDIENTE ADMINISTRATIVO. PLEITO DE RETIRADA DOS CRUCIFIXOS E DEMAIS SÍMBOLOS RELIGIOSOS EXPOSTOS NOS ESPAÇOS DO PODER JUDICIÁRIO DESTINADOS AO PÚBLICO. ACOLHIMENTO.}

A presença de crucifixos e demais símbolos religiosos nos espaços do Poder Judiciário destinados ao público não se coaduna com o princípio constitucional da impessoalidade na Administração Pública e com a laicidade do Estado brasileiro, de modo que é impositivo o acolhimento do pleito deduzido por diversas entidades da sociedade civil no sentido de que seja determinada a retirada de tais elementos de cunho religioso das áreas em questão. PEDIDO ACOLHIDO. [...]. (BRASIL, 2015, p. 1).

Existem, ainda, demandas em que a parte pleiteia, alegando motivo de cunho religioso, a realização de provas de concurso em horário diferenciado. A jurisprudência mais recente tende a indeferir tal pleito, com fundamento no princípio da igualdade, dentre outros. Nesse sentido, encontra-se a decisão do Conselho Nacional de Justiça (CNJ), de 16 de setembro de 2014, sinalizando a tendência de vedar a realização de provas de concurso público em horário especial, in verbis:

1. Adoto o bem lançado relatório do Conselheiro Fabiano Silveira, in verbis:

O requerente, candidato no concurso para Juiz de Direito Substituto do Tribunal de Justiça do Estado do Ceará, classificado para a segunda fase do certame, requer condição especial para realização da prova discursiva, invocando sua crença religiosa, que considera o sábado um dia santo, dedicado à adoração a Deus.

Afirma que sua convicção religiosa não permite atividades cotidianas desde o pôr do sol de sexta-feira até o pôr do sol de sábado, porém seu pedido para realizar a prova em horário diverso foi negado pela comissão do concurso.

Discorreu sobre a proteção constitucional à sua liberdade de crença e que pretende apenas iniciar a prova após o pôr do sol, ficando incomunicável até este horário.

Solicitei informações ao Tribunal que, em resposta, juntou a decisão exarada em outro pedido idêntico, onde foi indeferida a pretensão do candidato, sob o argumento de que a realização de provas em horários diferenciados fere os princípios da legalidade e da impessoalidade, consoante decidiu o STJ. 
$[\ldots]$

4. Dessa forma, seguindo o precedente desta Casa, bem como a jurisprudência da Suprema Corte, a medida liminar, apesar de o candidato já ter realizado a prova, não deve ser ratificada para manter alinhadas a jurisprudência deste Conselho com a do STF. 5. Ante o exposto, divirjo do Conselheiro Relator e voto pela não ratificação da liminar. (BRASIL, 2015, p. 2).

Em recente carta aberta ao Ministro do Supremo Tribunal Federal (STF) Luís Roberto Barroso, o juiz federal William Douglas ressaltou a importância da atual conjuntura, alegando estarmos "diante de um momento extremamente importante para o país, para o constitucionalismo e para a defesa do Estado Laico”. (DOUGLAS, 2015, p. 3).

A resolução desse tipo de demanda está longe de alcançar uma solução que agrade a todos, porquanto a questão do Estado laico é complexa.

\section{Aspectos históricos da Espanha}

A Espanha, no início do século XV, caracterizava-se por um conjunto de reinos com uma variada mistura de povos e culturas. $O$ território dividido nas seguintes regiões independentes: Galícia, Astúrias, Leon, Castela, Navarra, Aragão e Catalunha. Sem olvidar do Reino de Granada no extremo sul, o qual era dominado pelos mouros. (TURCI, 2010, p. 1).

Espanhóis, mouros, italianos, portugueses e uma das maiores comunidades de judeus de toda a Europa conviviam nos portos e centros urbanos dos respectivos reinos. Situação essa que perdurou por um longo período, até o casamento de Isabel - rainha de Castela - com o rei Fernando II de Aragão, que representou um grande marco para a formação espanhola, já que Castela e Aragão consistiam nos reinos católicos mais influentes da região, e, os hispânicos lideravam em desfavor dos invasores mouros desde o início da Guerra da Reconquista, no século VIII.

A Reconquista, também denominada Conquista Cristã, iniciou-se no século VII (ano de 718) e se caracterizou pelo combate entre os reinos cristãos do norte da Península Ibérica contra a dominação islâmica do resto da Península. O processo da Reconquista de todo o território peninsular durou cerca de sete séculos e foi concluída em 1942 com a tomada do reino muçulmano de Granada pelos Reis Católicos.

O processo de centralização política que se originou a partir daí foi lento e marcado por inúmeros conflitos, tendo em vista que as ligas dos nobres, denominadas banderías, recusavam-se a aceitar o domínio castelhano e aragonês. Porém, Isabel e Fernando, ou Reis Católicos como eram chamados, "souberam canalizar os interesses 
militaristas e religiosos dos hispânicos para a Guerra da Reconquista contra os inimigos mouros". (TURCI, 2010, p. 2).

Em janeiro de 1492, o reino mouro de Granada foi tomado pelos espanhóis, restando configurado o triunfo da união espanhola. Desse modo, puderam Fernando e Isabel avançar em suas pretensões de um reino unificado.

O Estado espanhol em formação era católico e intimamente relacionado ao Papa Alexandre VI, que era espanhol e foi eleito Papa em 1492. A aliança entre os reis e a Igreja viabilizou a instauração de uma Inquisição com grande força na Espanha, cujo papel exercido era, muitas vezes, de perseguidora política, em defesa dos interesses dos Reis Católicos.

Do mesmo modo que almejavam aumentar seu por poder por meio de conquistas territoriais e da expansão marítima, os Reis Católicos buscavam, no âmbito interno, a criação de uma identidade cultural entre os hispânicos. Para tanto, incentivavam o preconceito, sobretudo contra negros, mouros, judeus e ciganos.

Atrelados à sua estratégia de unificação do reino, os espanhóis decretaram a expulsão dos judeus e dos mouros que não quiseram se converter ao catolicismo, em 1492, mesmo ano em que venceram os mouros em Granada.

Foi também em 1942 que os espanhóis financiaram Cristóvão Colombo a sair em busca das Índias. "Colombo daria para o reino espanhol o poder que nenhum outro reino europeu possuía: colônias riquíssimas em ouro e prata, além de terras férteis e povos para serem explorados”. (TURCI, 2010, p. 5).

Em suma, o reinado de Isabel e Fernando II, conforme acima mencionado, representou um marco na história espanhola, considerando seu empenho em promover a unificação e expansão da Espanha.

Nesse sentido, o referido reinado foi marcado pelas seguintes características: luta pela centralização política e unificação cultural, baseada na intolerância religiosa e no militarismo; desenvolvimento científico e humanista amparados pela Universidade de Salamanca; guerras pela conquista de regiões italianas e expansão marítima e comercial atlântica incentivadas pela concorrência com Portugal.

No entanto, mais do que simplesmente representar o reinado de Isabel e Fernando II, essas questões são fundamentais para a compreensão da Espanha do século XV, sobretudo porque, a partir de suas conquistas, a Espanha tornou-se o maior Império da Idade Moderna.

Verifica-se, então, que a formação do Reino da Espanha está intimamente relacionada ao catolicismo, de modo que este foi fundamental para o processo de centralização política e unificação cultural da Espanha.

Considerando-se a tradição histórica espanhola, em que se restou configurada a presença marcante do catolicismo, e trazendo para os dias atuais, José Ramón Montero explica que: 
Na recente democracia espanhola, o desenvolvimento das novas relações entre religião e política foi tornado possível pela combinação entre as estratégias das elites políticas e as mudanças sociais que se inscrevem sob o termo secularização. Ambos os factores contribuíram para criar um clima religioso até então desconhecido, presidido pela decisão de evitar conflitos e caracterizado por um crescente pluralismo nas distribuições ideológicas e preferências partidárias dos grupos religiosos. Os níveis de consenso e secularização alcançados pelos Espanhóis tornam já sumamente improváveis os confrontos por motivos religiosos: a religião deixou de surgir como um elemento fundamentalmente divisor ou polarizador. (MONTERO, 1998, p. 1053).

A despeito de uma herança católica profunda na história espanhola, é possível perceber, nos dias de hoje, a existência de processos de afastamento da Igreja enquanto instituição, assim como a perda de força das crenças religiosas e a diminuição das práticas religiosas. Resultado de diversos fatores, dentre eles, uma crescente secularização, um processo de individualização de consciência, bem como uma postura da própria Igreja católica, que buscou rever suas posições em relação à ditadura, no período conhecido como transição.

Atualmente, a situação espanhola se caracteriza ao mesmo tempo pela secularização crescente e pela persistência do religioso. Nota-se também a hegemonia cultural do catolicismo, conforme dito.

Do exposto, infere-se que existe uma tendência à diminuição da influência católica na sociedade espanhola. Contudo, há que se reconhecer que, do ponto de vista histórico, a igreja católica sempre terá um significado intenso para os espanhóis.

\section{Laicidade no ordenamento jurídico espanhol}

O constituinte espanhol adotou a laicidade do Estado, garantindo a liberdade de expressão, informação, formação de convicção e de culto dos indivíduos e das comunidades, nos moldes do art. 16.3 da CE.

Destaque-se que o termo utilizado pelo legislador espanhol é "aconfessionalidad". Nesse sentido, conforme o magistério de Adriane Reis Araujo: “O Estado 'aconfessional' é aquele que não adota ou reconhece nenhuma religião como oficial, ainda que possa ter acordos de colaboração ou ajuda econômica com algumas instituições religiosas". (ARAUJO, 2014, p. 11).

A laicidade espanhola encontra amparo no art. 16 da Constituição Espanhola, a seguir transcrito: 


\section{Artículo 16}

1. Se garantiza la libertad ideológica, religiosa y de culto de los individuos y las comunidades sin más limitación, en sus manifestaciones, que la necesaria para el mantenimiento del orden público protegido por la ley.

2. Nadie podrá ser obligado a declarar sobre su ideología, religión o creencias.

3. Ninguna confesión tendrá carácter estatal. Los poderes públicos tendrán en cuenta las creencias religiosas de la sociedad española y mantendrán las consiguientes relaciones de cooperación con la Iglesia Católica y las demás confesiones. (ESPANHA, 2015. p. 3).

Desse modo, o texto constitucional espanhol garante a liberdade ideológica e de culto dos indivíduos e das comunidades, limitando-as, caso necessário, somente para a manutenção da ordem pública.

Como garantia de liberdade de pensamento, o texto constitucional espanhol prevê também a obrigação estatal de manter relações de cooperação com a Igreja Católica e demais confissões religiosas (art. 16.3, CE).

Em decorrência, foi firmado um acordo entre a Santa Sé e a Espanha ("Sobre enseñanza y asuntos culturales"), em 4 de dezembro de 1979, garantindo-se o direito, a todos os alunos espanhóis, de se receber ensino religioso nas escolas, no ensino pré-escolar e no fundamental. A disciplina, a qual é equivalente às outras matérias fundamentais, é oferecida nos colégios, públicos e privados, nos horários regulares de aula, e apresenta-se como opção voluntária.

$\mathrm{O}$ art. 16 da Constituição Espanhola constitucionaliza a liberdade ideológica como liberdade de pensamento. Nesse diapasão, Conde e Ausina ensinam que:

[...] La Constituición no se limita a reconocer la libertad ideológica, concebida esta como el derecho de toda persona a la formación de un sistema de ideas que representan una determinada concepción global del mundo, sino también las diversas formas de manifestación de la misma, cuestión esta que adquiere una mayor relevancia jurídica y política, porque es precisamente en la manifestación de la libertad ideológica donde se plantean los problemas derivados de los límites inherentes a la misma, ya que en su consideración de simple libertad de pensamiento la libertad ideológica no parece tener límite alguno. Es decir, la Constituición no limita la libertad ideológica, sino tan solo su manifestación, garantizándose cualquier ideología, incluso la contraria a la propia Constituición. (CONDE; AUSINA, 2014, p. 318). 
Do exposto, infere-se que a norma fundamental espanhola ampara a difusão de ideologias e/ou projetos políticos incompatíveis com os valores democráticos, desde que estes respeitem as regras do jogo democrático.

No entanto, verifica-se um desencontro entre a jurisprudência constitucional e a da Corte Europeia de Direitos Humanos - CEDH (também chamado de Tribunal Europeu de Direitos Humanos ou Tribunal de Estrasburgo), na medida em que a corte mencionada adverte expressamente que nem a liberdade ideológica, nem a de expressão, nem o direito de associação política amparam a difusão de ideologias ou projetos políticos ou a existência de partidos políticos que desrespeitem os valores democráticos, a exemplo de propostas nazistas ou fundamentalistas.

A CEDH defende que tanto o projeto político quanto os meios para atingi-los devem respeitar e ser compatíveis com a democracia.

Importa destacar que a Constituição Espanhola estabeleceu dois limites expressos às manifestações da liberdade ideológica, quais sejam: a manutenção da ordem pública protegida pela lei e a impossibilidade de ser obrigado a declarar sobre a própria ideologia.

O desenvolvimento legislativo da liberdade religiosa na Espanha se deu através da "Ley Orgánica 7/1980", de 5 de julho. A liberdade religiosa apresenta duas questões fundamentais, quais sejam: o próprio conteúdo e significado da referida liberdade e a posição do Estado em relação ao fenômeno religioso, ambas as questões relacionadas entre si.

Primeiramente, a liberdade religiosa configura-se como um direito individual e coletivo, pois se refere tanto aos indivíduos quanto às comunidades que a professam. $\mathrm{O}$ artigo 2 da lei retro mencionada reconhece os seguintes direitos:

- El derecho a profesar las creencias religiosas que libremente se elijan o el derecho a no profesar ninguna, lo cual comprende también el derecho a cambiar de confesión o abandonar la que se profesaba.

- El derecho a practicar los actos de culto, entre los cuales hay que mencionar el derecho a recebir asistencia religiosa, conmemorar sus festividades y celebrar sus ritos, así com el de no ser obligado a practicar ningún tipo de actos de culto.

- El derecho a recibir e impartir ensañanza e información religiosa de toda índole, que comprende el derecho a elegir la educación religiosa y moral que este de acuerdo con sus propias convicciones. - El derecho a reunirse y manifestarse públicamente con fines religiosos, así como el de asociarse para desarrollar ese tipo de actividad. (ESPANHA, 2015. p. 1). 
Nesse sentido, vasta é a legislação referente aos direitos humanos, nos quais se inclui a liberdade religiosa, a exemplo da Declaração Universal dos Direitos Humanos (art. 18), do Convênio de Roma (art. 9º), do Pacto Internacional de Direitos Civis e Políticos (art. 18) e da Carta de Nice (art. 10).

Concernentemente aos limites do direito à liberdade religiosa, verificou-se que o art. 16 estabeleceu o limite de ordem pública e a impossibilidade de ser obrigado a declarar acerca de sua religião ou crenças. Dessa forma, a despeito da inadequação da expressão “ordem pública”, o art. 3 da "Ley de Libertad Religiosa” estabelece os três aspectos que caracterizam a ordem pública em uma sociedade democrática, sendo eles: segurança, saúde e moralidade pública.

Além de ser um direito individual, o direito à liberdade religiosa abarca também as confissões e as comunidades religiosas, de modo que o art. 2 da "Ley de Libertad Religiosa" garante "[...] el derecho a establecer lugares de culto o de reunión con fines religiosos, a designar y formar sus ministros, a divulgar y a propagar su propio credo y a mantener relaciones con sus propias organizaciones o con otras confesiones religiosas." (CONDE; AUSINA, 2014, p. 323).

$\mathrm{O}$ art. 16.3 estabelece que nenhuma confissão terá caráter estatal, em decorrência da proclamação da liberdade religiosa e de cultos. No entanto, é preciso asseverar que este princípio da separação entre a Igreja e o Estado não implica em desconhecimento mútuo entre ambos, tendo em vista o disposto no próprio preceito, a seguir transcrito: "Los poderes públicos tendrán en cuenta las creencias religiosas de la sociedad y mantendrán las consiguientes relaciones de cooperación com la Iglesia católica y las demás confesiones".

Destaque-se que o referido dispositivo menciona expressamente a Igreja católica, de modo que é possível inferir a presença de uma confessionalidade sociológica do Estado.

Para Conde e Ausina, um fato é a proclamação do Estado laico, o que significa que nenhuma confissão terá caráter estatal, de acordo com o estabelecido na Constituição da Espanha; outro muito diferente consiste na aceitação do "laicismo estatal", em que se verifica uma questão antirreligiosa, que não se encontra presente no ordenamento jurídico espanhol, do qual se encontra excluída unicamente a confessionalidade do Estado. (CONDE; AUSINA, 2014, p. 324).

No que se refere ao princípio de cooperação, caracterizado como o sistema de relações entre a Igreja e o Estado, percebe-se seu desenvolvimento a partir da já mencionada "Ley de Libertad Religiosa", que prevê a existência de um registro público para que as igrejas, confissões e comunidades religiosas possam adquirir personalidade jurídica.

Ademais, o referido preceito constitucional (art. 16.3 da CE) estabelece, ainda, a possibilidade de acordos ou convênios com essas entidades, criando-se a 
denominada "Comisión Asesora de Libertad Religiosa", relacionada às questões relativas a essa temática.

Importa destacar a existência de acordos firmados entre o Estado espanhol e a Santa Sé, sendo estes de quatro tipos, a saber: acordos que versam sobre assuntos jurídicos; assuntos econômicos; ensino e assuntos culturais; sobre assistência religiosa às Forças Armadas e o serviço militar de cléricos e religiosos.

Faz-se necessário mencionar as leis 24, 25 e 26/1992 de 10 de novembro, porquanto se tratam de acordos de cooperação do Estado com diversas confissões religiosas, tais como a "Federeción de Entidades Religiosas Evangélicas de España", a "Federación de Comunidades Israelitas de España” e a “Comisión Islámica de España”.

Acerca da liberdade religiosa, Conde e Ausina aduzem que:

Sobre el tema de la libertad religiosa existen no pocas cuestiones polémicas que obligan a considerar constantemente su configuración consticuional, así como su compatibilidade con otros principios y derechos: piénsese en la presencia de los símbolos religiosos en las aulas (que exige tomar como referencia la neutralidade del Estado - entendida como favorecimiento de las diversas religiones - en un ámbito especialmente sensible como el educativo) y en las tomas de posesión de altos cargos (que habría de producirse desde el respeto a la libertad individual); el uso de símbolos religiosos por algunos miembros de confesiones religiosas (la polémica del velo, que necesariamente se conecta con la igualdad de género); la cuestión de la financiación religiosa, o las opciones políticas y éticas de los dirigentes de las confesiones religiosas, lo que abre en muchas ocasiones el debate sobre la reforma de la Ley Orgánica de Libertad Religiosa. Por el momento, sin embargo, los intentos de reforma no han prosperado. (CONDE; AUSINA, 2014, p. 325).

Conforme Ollero, "la Constituición española de 1978 no contiene, ni en su preámbulo ni en su texto articulado referencia expresa alguna a Dios” (OLLERO, p. 1). Todavia, não é por isso que se deve considerar o Estado laico, o que deverá ser feito apenas após a análise maior dos direitos e das liberdades fundamentais garantidos pela Constituição espanhola, bem como a partir da compreensão do próprio conceito de laico.

\section{Uma análise comparativa da laicidade nos ordenamentos jurídicos brasileiro e espanhol}

Após a exposição dos aspectos históricos, conceituais e constitucionais acerca da laicidade no Brasil e na Espanha, torna-se necessário comparar a laicidade nos dois sistemas jurídicos, utilizando-se, para tanto, a metodologia do Direito Comparado. 
Do ponto de vista histórico, observou-se que tanto o Brasil como a Espanha possuem um processo histórico intimamente associado à tradição religiosa, a saber: o catolicismo. Contudo, a tradição histórica espanhola possui uma relação mais longínqua com a Igreja Católica, tempos estes que remontam à Roma Antiga.

Quanto ao Brasil, apenas se pode falar na relação do Estado com a Igreja Católica a partir da sua colonização por Portugal, em 1500. O que, por sua vez, não diminui a intensidade dessa relação.

Nesse sentido, a despeito dessa ligação e do todo o processo de separação entre o Estado e a Igreja, é preciso analisar em que medida é possível encontrar pontos de convergência e de divergência entre os ordenamentos jurídicos brasileiro e espanhol no que se refere à laicidade.

Uma questão primordial a se tratar diz respeito ao fato de o Brasil ser denominado Estado laico, enquanto que na Espanha, utiliza-se, muitas vezes, a denominação de Estado “aconfesional”, embora muitos textos referem-se à Espanha como um Estado laico.

Saliente-se que o Estado laico é aquele que independe de qualquer organização ou confissão religiosa, sendo que as autoridades políticas não aderem, de maneira pública, a nenhuma religião determinada, de modo que as crenças religiosas não influem na política nacional.

Diferentemente, o Estado "aconfesional" é aquele que não adere e não reconhece como oficial nenhuma religião em concreto, ainda que tenha acordos colaborativos ou de ajuda econômica com algumas instituições religiosas.

Feitas essas considerações, acredita-se ser correta a denominação do Estado espanhol como "aconfesional", ainda que, muitas vezes, exista uma confusão entre esses conceitos, que são largamente utilizados como sinônimos.

De outro modo, acredita-se ser equivocado denominar o Brasil como Estado laico, porquanto, embora não possua uma religião oficial, realiza uma série de acordos com instituições religiosas, inclusive, com respaldo do texto constitucional.

É o que se verifica no art. $5^{\circ}$, VII, da Constituição Federal que assegura a prestação de assistência religiosa nas entidades civis e militares de internação coletiva, assim como a exceção dada à restrição estabelecida no art. 19, em que não existe vedação para a colaboração, quando realizada com o fim de interesse público.

De início, a Constituição da República Federativa do Brasil de 1988 invoca a proteção de Deus, conforme Preâmbulo a seguir transcrito:

Nós, representantes do povo brasileiro, reunidos em Assembléia Nacional Constituinte para instituir um Estado Democrático, destinado a assegurar o exercício dos direitos sociais e individuais, a liberdade, a segurança, o bem-estar, o desenvolvimento, a igualdade e a justiça como valores supremos de uma sociedade 
fraterna, pluralista e sem preconceitos, fundada na harmonia social e comprometida, na ordem interna e internacional, com a solução pacífica das controvérsias, promulgamos, sob a proteção de Deus, a seguinte CONSTITUIÇÃO DA REPÚBLICA FEDERATIVA DO BRASIL. (BRASIL, 2015, p. 1).

Nesse sentido, já é possível notar uma diferença entre ambos os sistemas, porquanto "a Constituição Espanhola de 1978 não contém, nem sem seu preâmbulo nem em seu texto articulado referência expressa a Deus" (OLLERO, p. 1). Desse modo, se é possível falar em laicidade sob uma perspectiva gradativa, a Espanha mais se aproxima de um Estado laico do que o Brasil.

Nos textos constitucionais brasileiro e espanhol, encontram-se a garantia da liberdade de consciência e de crença, no art. 5º, VI e VII da Constituição de 1988 e do art. 16.1 da Constituição Espanhola de 1978.

$\mathrm{O}$ art. 16 estabeleceu que a garantia da liberdade ideológica, religiosa e de culto pode sofrer duas limitações: a necessária à manutenção da ordem pública protegida pela lei e a impossibilidade de alguém ser obrigado a declarar a sua própria ideologia. A única vedação existente na Constituição brasileira encontra-se disposta no art. 19, inciso I, e preconiza que é vedado aos entes federativos estabelecer, subsidiar ou atrapalhar o funcionamento dos cultos religiosos ou igrejas, bem como manter com estas relações de dependência ou aliança, salvo a colaboração de interesse público.

$\mathrm{O}$ art. 16.3 da Constituição Espanhola dispõe que nenhuma confissão terá caráter estatal. Identifica-se, assim, a previsão do Estado laico no ordenamento jurídico espanhol. No entanto, essa separação entre Estado e Igreja deve ser interpretada de forma relativizada, uma vez que o mesmo dispositivo aduz que o poder público irá considerar as crenças religiosas da sociedade espanhola e manterá relações de cooperação com a Igreja Católica e com as demais confissões.

Aqui, verifica-se outro ponto de convergência entre o sistema jurídico brasileiro e o espanhol, a saber: a questão das relações de assistência, prestação e cooperação entre o Estado e a religião. No caso brasileiro, o art. $5^{\circ}$, inciso VII, da Constituição estabelece a prestação de assistência religiosa nas entidades civis e militares de internação coletiva. No ordenamento jurídico espanhol, de acordo com o artigo 16.3, apresenta-se o princípio de cooperação, em que existe a possibilidade de realização de acordos ou convênios com as entidades religiosas.

No que diz respeito à questão do ensino religioso, cabe mencionar que, no Brasil, existe a permissão de ensino religioso em escola pública, ainda que de matrícula facultativa, a teor do art. $210, \S 1^{\circ}$, do texto fundamental.

O caso espanhol é muito semelhante, na medida em que um acordo firmado entre a Santa Sé e a Espanha, em 1979, garantiu o direito, a todos os alunos espanhóis, de receber ensino religioso nas escolas, no ensino pré-escolar e fundamental. De igual 
modo, a opção a esse tipo de ensino é voluntária. Diferentemente do que ocorre no Brasil, essa garantia de ensino religioso é ofertada tanto nos colégios públicos quanto nos particulares.

Observa-se que a Constituição da República Federativa do Brasil de 1988 é mais abrangente que a Constituição Espanhola de 1978, contando com mais dispositivos. Esse dado influencia a presente análise, na medida em que a laicidade na Constituição Espanhola está basicamente tratada no art. 16, itens 1, 2 e 3 . No caso brasileiro, é possível notar a presença da laicidade em dispositivos esparsos inseridos no atual texto constitucional, a exemplo do art. $5^{\circ}$, incisos VI e VIII; 19; 150, inciso VI, alínea $b$; 226; dentre outros.

Não obstante, a análise da laicidade nos ordenamentos jurídicos brasileiro e espanhol ultrapassa os limites das garantias e dos direitos dispostos em suas respectivas constituições, sendo aquela também objeto de constante construção doutrinária e jurisprudencial. A seguir, apresenta-se um caso controverso, que chegou ao judiciário do Brasil e da Espanha, qual seja, a transfusão de sangue em testemunhas de jeová.

Em 18 de julho de 2002, ocorreu, na Espanha, a decisão do caso 154/2002, que revisou uma sentença que havia condenado os pais do menor Marcos Vallés, testemunhas de jeová, por homicídio, diante da negativa destes em obrigar o filho, também pertencente à mesma igreja, a receber uma transfusão de sangue, conduta proibida por sua religião (AZEVEDO, 2007, p. 1).

O caso gerou grande comoção, sendo acompanhado por centenas de testemunhas de Jeová e ganhando visibilidade na mídia, que ocasionou, por sua vez, uma leva de reprovação por parte da opinião pública.

Quanto ao julgamento, os pais foram absolvidos do crime de "homicídio por omissão" em primeira instância. Já em segunda instância, foram condenados como autores responsáveis do delito de homicídio. Por fim, o Supremo Tribunal Constitucional Espanhol decidiu pela absolvição dos pais de Marcos (Pedro Alegre Tomás e Lina Vallés Rausa).

Ressalte-se que o texto da decisão do caso 154/2002 "possui grande relevância tanto como construção doutrinária quanto como fundamentação jurisprudencial" (AZEVEDO, 2007, p. 6). A posição do Tribunal Constitucional discorreu sobre vários tópicos, entre eles: o menor como titular do direito à liberdade religiosa, a capacidade do menor, o conflito entre direitos fundamentais, a saúde pública como saúde em geral e a conduta dos pais e nexo de causalidade com o resultado morte.

Com base em farta doutrina e jurisprudência citadas na decisão, o Tribunal Constitucional posicionou-se no sentido de que as convicções invocadas pelos pais não consistiram em um obstáculo à proteção da vida do menor, porquanto não se poderia exigir que os pais atuassem de modo a convencer o próprio filho ou, ainda, que permitissem diretamente a transfusão. Desse modo, a decisão do Tribunal seguiu o entendimento que: 
[...] a exigência de uma ação persuasiva ou permissiva com a transfusão confrontaria a essência do direito à liberdade religiosa, indo além do dever exigível em virtude de sua posição jurídica para com o menor, não cabendo à condição de garantidor dos pais se estender ao cumprimento de tais exigências. A atuação dos recorrentes encontrar-se-ia integralmente amparada no direito fundamental à liberdade religiosa, prevista no art. 16.1 CE, resguardando a incolumidade de sua atitude omissiva. (AZEVEDO, 2007, p. 11).

Nota-se que, no ordenamento jurídico constitucional espanhol, o direito à vida deve ser considerado como um valor superior. Contudo, para a decisão em comento, não houve conflito de direitos, no caso entre o direito à liberdade religiosa e o direito à vida, na medida em que os pais não se opuseram às decisões judiciais que autorizaram a transfusão de sangue. Dessa forma, a contraposição entre os direitos mencionados não chegou a se realizar.

Em consulta à jurisprudência no sítio do Supremo Tribunal Federal (STF), não foram localizadas jurisprudências sobre a questão da transfusão de sangue em testemunhas de Jeová, assim como em pesquisa ao sítio do Superior Tribunal de Justiça (STJ).

De outro modo, na primeira instância, a jurisprudência acerca da transfusão de sangue em testemunha de Jeová é vasta. A seguir, apresentam-se dois julgados do Tribunal de Justiça do Rio Grande do Sul, com posicionamentos diversos. Confiram-se:

AGRAVO DE INSTRUMENTO. DIREITO PRIVADO NÃO ESPECIFICADO. TESTEMUNHA DE JEOVÁ. TRANSFUSÃO

DE SANGUE. DIREITOS FUNDAMENTAIS. LIBERDADE DE CRENÇA E DIGNIDADE DA PESSOA HUMANA. PREVALÊNCIA. OPÇÃO POR TRATAMENTO MÉDICO QUE PRESERVA A DIGNIDADE DA RECORRENTE. A decisão recorrida deferiu a realização de transfusão sanguínea contra a vontade expressa da agravante, a fim de preservar-lhe a vida. A postulante é pessoa capaz, está lúcida e desde o primeiro momento em que buscou atendimento médico dispôs, expressamente, a respeito de sua discordância com tratamentos que violem suas convicções religiosas, especialmente atransfusão de sangue. Impossibilidade de ser a recorrente submetida a tratamento médico com o qual não concorda e que para ser procedido necessita do uso de força policial. Tratamento médico que, embora pretenda a preservação da vida, dela retira a dignidade proveniente da crença religiosa, podendo tornar a existência restante sem sentido. Livre arbítrio. Inexistência do direito estatal de "salvar a pessoa dela própria", quando sua escolha não implica violação de direitos 
sociais ou de terceiros. Proteção do direito de escolha, direito calcado na preservação da dignidade, para que a agravante somente seja submetida a tratamento médico compatível com suas crenças religiosas. AGRAVO PROVIDO. (BRASIL, 2015, p. 1).

Em sentido oposto, o julgado a seguir segue o entendimento de que o médico deve empreender todos os esforços necessários ao adequado tratamento do paciente, independentemente do consentimento deste ou de seus familiares. Veja-se:

\author{
APELAÇÃO CÍVEL. TRANSFUSÃO DE SANGUE. \\ TESTEMUNHA DE JEOVÁ. RECUSA DE TRATAMENTO. \\ INTERESSE EM AGIR. Carece de interesse processual o hospital \\ ao ajuizar demanda no intuito de obter provimento jurisdicional \\ que determine à paciente que se submeta à transfusão de sangue. \\ Não há necessidade de intervenção judicial, pois o profissional de \\ saúde tem o dever de, havendo iminente perigo de vida, empreender \\ todas as diligências necessárias ao tratamento da paciente, \\ independentemente do consentimento dela ou de seus familiares. \\ Recurso desprovido. (BRASIL, 2015, p. 1).
}

O debate sobre a laicidade é profícuo e com cada decisão tomada e posicionamento defendido, corre-se o risco de ocorrer reducionismos, tamanha é a amplitude da questão e importância dada ao direito à liberdade religiosa. Cabe incluir na discussão que a chegada do século XXI trouxe questões cruciais a respeito dos direitos fundamentais, face à pluralidade e à diversidade cultural presente tanto na Espanha quanto no Brasil, demonstrando a relevância do estudo que ora se propõe.

\title{
8 Considerações finais
}

O direito à liberdade religiosa consiste em assunto de destaque no atual cenário mundial e brasileiro, dado que cada vez mais se percebe a existência de uma sociedade plural com grande diversidade cultural, a qual necessita ter seus direitos fundamentais respeitados.

É nesse contexto que se encontrou, no Estado laico, uma forma de se garantir este direito tão elementar e caro aos indivíduos e à coletividade de um modo geral. Pelo exposto, é que se verifica que a temática da análise comparativa da laicidade nos ordenamentos jurídicos brasileiro e espanhol, enquanto problemática abordada neste artigo, é relevante.

A abordagem comparativa da laicidade nestes países demonstrou que existem muitas semelhanças em ambos os ordenamentos jurídicos, mas também apontou 
algumas diferenças. Assim, os dois Estados podem contribuir um ao outro, no que tange à construção doutrinária e jurisprudencial da laicidade.

No estudo comparativo sobre a laicidade no sistema jurídico brasileiro e no sistema jurídico espanhol, procurou-se evidenciar o processo pelo qual se desenvolveu o Estado laico nos Estados mencionados, compreendendo o instituto da laicidade e a sua importância nos dias de hoje.

O trabalho foi estruturado de forma a contemplar os aspectos a seguir mencionados. Primeiramente, buscou construir um conceito de laicidade. Em seguida, procurou-se narrar aspectos históricos do Brasil e como a laicidade se apresenta no ordenamento jurídico brasileiro. Após, apresentou-se aspectos históricos da Espanha e a maneira pela qual a laicidade se faz presente no sistema jurídico espanhol. Pro fim, realizou-se uma análise comparativa da laicidade nos respectivos ordenamentos jurídicos.

Do ponto de vista histórico, verificou-se que ambos os países foram fundados sob a égide da religião católica, tradição esta que permanece nos dias de hoje, exercendo, ainda, enorme influência nestes Estados.

Sob o aspecto constitucional, nota-se que os dois ordenamentos jurídicos defendem a liberdade de crença e de religião, a teor do art. $5^{\circ}$, inciso VI (e outros dispositivos), da Constituição da República Federativa do Brasil de 1988 e do art. 16 da Constituição da Espanha de 1978, podendo-se extrair destes dispositivos que ninguém poderá ser forçado a praticar atos contrários à sua consciência, nem ser impedido de agir conforme suas crenças individuais.

Em contrapartida, não pode o Estado prejudicar ou beneficiar nenhuma crença particular, devendo, antes, adotar uma postura de neutralidade e tolerância com todas as religiões e confissões religiosas existentes, sem hostilidade ou proselitismo.

A despeito de ser uma garantia constitucional, a liberdade religiosa, como toda garantia, não é absoluta, encontrando limites no próprio ordenamento jurídico. É o que se verificou com o caso de transfusão de sangue em testemunha de jeová, conforme abordado neste artigo.

A respeito da transfusão de sangue em testemunha de jeová percebeu-se que esse tipo de caso (hard case) é encontrado tanto na jurisprudência brasileira quanto na espanhola, sendo sempre um caso de difícil resolução, porquanto o direito à liberdade religiosa se esbarra no direito à vida, em geral considerado de maior relevância. Ainda que exista jurisprudência no sentido de que de nada adianta ter a vida garantida se esta não puder ser vivida de acordo com as crenças individuais.

Embora grande parte da população, não somente no caso brasileiro, mas também no caso espanhol, professe religiões de origem cristã (católicos e evangélicos), o Brasil e a Espanha são países laicos, ao menos em termos constitucionais, e, por conta disso, é necessário que mantenham uma posição de neutralidade em relação às diferentes 
concepções religiosas observadas na sociedade. Ainda assim, nota-se que o Estado, muitas vezes, toma posições em questões de fé, estabelecendo preferências, de modo a privilegiar uns e ignorar outros.

Por todo o exposto, conclui-se que a problemática enfrentada neste artigo, a saber: uma análise comparativa da laicidade nos ordenamentos jurídicos brasileiro e espanhol, apresentou significativa contribuição sobre a importância de se proteger e defender o direito à liberdade religiosa. Nesse sentido, considerando-se que o desenvolvimento de um Estado laico consiste em processo de constante construção, o estudo sobre a laicidade é primordial para o alcance das garantias constitucionais. 


\section{Referências}

ARAUJO, Adriane Reis de. A liberdade religiosa do professor de religião na Espanha: análise da empresa de tendência. In: Conselho Nacional do Ministério Público. Ministério Público em defesa do Estado laico. Brasília: CNMP, 2014.

AZEVEDO, Eduarda Peixoto de. Jurisprudência constitucional espanhola: o exercício da liberdade religiosa no Caso 154/2002. Rio de Janeiro: Pontifícia Universidade Católica do Rio de Janeiro, 2007. Disponível em: <http://www.puc-rio.br/pibic/relatorio_resumo2007/relatorios/ dir/dir_eduarda_peixoto_azevedo.pdf $>$. Acesso em: 31 out. 2015.

BÍBLIA. Português. Bíblia Sagrada Ave Maria. Tradução dos originais grego, hebraico e aramaico mediante a versão dos Monges. São Paulo: Editora Ave-Maria, 2008.

BLANCARTE, Roberto. O porquê de um Estado laico. In: LOREA, Roberto Arriada (org.). Em defesa das liberdades laicas. Porto Alegre: Livraria do Advogado Editora, 2008.

BRASIL. Conselho Nacional de Justiça. Medida Liminar em Pedido de Providências (ML em PP). Processo no 0003657-86.2014.2.00.0000. Conselheiro Relator: Guilherme Calmon Nogueira da Gama. Data de julgamento: 16 set. 2014. Brasília, 16 set. 2015. Disponível em: <http://www.cnj.jus.br/InfojurisI2/Jurisprudencia.seam;jsessionid=C02DA32D3BF0C05917900195A4805500.node2?jurisprudenciaIdJuris=47422\&indiceListaJurispruden$\mathrm{cia}=4 \&$ firstResult $=5850 \&$ tipoPesquisa $=\mathrm{BANCO}>$. Acesso em: 31 out. 2015.

BRASIL. Constituição (1824). Constituição Política do Imperio do Brazil. Disponível em: $<$ http://www.planalto.gov.br/ccivil_03/Constituicao/Constituicao24.htm>. Acesso em: 29 ago. 2015.

BRASIL. Constituição (1891). Constituição da República dos Estados Unidos do Brasil. Disponível em: <http://www.planalto.gov.br/ccivil_03/Constituicao/Constituicao91.htm>. Acesso em: 29 ago. 2015.

BRASIL. Constituição (1988). Constituição da República Federativa do Brasil. Disponível em: $<$ http://www.planalto.gov.br/ccivil_03/constituicao/constituicao.htm>. Acesso em: 29 ago. 2015. BRASIL. Decreto no 119-A, de 7 de janeiro de 1890. Prohibe a intervenção da autoridade federal e dos Estados federados em matéria religiosa, consagra a plena liberdade de cultos, extingue o padroado e estabelece outras providencias. Coleção de Leis do Brasil, 1890. Disponível em: <http://www.planalto.gov.br/ccivil_03/decreto/1851-1899/d119-a.htm>. Acesso em: 29 ago. 2015.

BRASIL. Superior Tribunal de Justiça. Ação Penal contra médico que impediu transfusão sanguínea continua. STJ Online, Brasília, 6 nov. 1998. Disponível em: <http://www.stj.jus.br/sites/ STJ/default/pt_BR/noticias/noticias/\%C3\%9Altimas/A\%C3\%A7\%C3\%A3o-Penal-contra-m\%C3\%A9dico-que-impediu-transfus\%C3\%A3o-sang\%C3\%BC\%C3\%ADnea-continua $>$. Acesso em: 31 out. 2015.

CONDE, Enrique Álvarez; AUSINA, Rosario Tur. Derecho Constitucional. 4. ed. Madrid: Tecnos, 2014. 
DOUGLAS, William. Ensino Religioso: carta aberta ao ministro Barroso. JusBrasil, Rio de Janeiro, set. 2015. Disponível em: <http://williamdouglas.jusbrasil.com.br/artigos/222029205/ ensino-religioso $>$. Acesso em: 23 ago. 2015.

ESPANHA. Constituição (1978). La Constituición de la España. Madri: Senado, 1978. Disponível em: <http://www.jurisciencia.com/vademecum/constituicoes-estrangeiras/a-constituicaoda-espanha-la-constitucion-de-la-espana/382/>. Acesso em: 23 set. 2015.

ESPANHA. Ley Orgánica no 7, de 5 de julho de 1980. De libertad religiosa. Disponível em: <http://noticias.juridicas.com/base_datos/Admin/lo7-1980.html>. Acesso em: 3 out. 2015.

LACERDA, Gustavo Biscaia de. Sobre as relações entre Igreja e Estado: conceituando a laicidade. In Conselho Nacional do Ministério Público. Ministério Público em defesa do Estado laico. Brasília: CNMP, 2014.

MENDES, Gilmar Ferreira; BRANCO, Paulo Gustavo Gonet. Curso de Direito Constitucional. 6. ed. rev. e atual. São Paulo: Saraiva, 2011.

MIRANDA, Jorge. Estado, liberdade e laicidade. Revista Gaudium Sciendi, Portugal, n. 4, jul. 2013.

MONTERO, José Ramón. Religião e política em Espanha: os novos contornos da clivagem religiosa. Análise Social, v. XXXIII, n. 149, p. 1053-1077, 1998.

MORAES, Alexandre de. Direito Constitucional. 28. ed. São Paulo: Atlas, 2012.

NUTO, João Vianney Cavalcanti; ALCÂNTARA, Pedro Ivo Souza de. O uso de símbolos religiosos em repartições públicas: uma análise histórica sobre o alcance da laicidade. In: Conselho Nacional do Ministério Público. Ministério Público em defesa do Estado laico. Brasília: CNMP, 2014.

OLLERO, Andrés. Laicidad y laicismo en el marco de la Constituición bEspañola. Madri: Universidad Rey Juan Carlos, [s. d.].

RIO GRANDE DO SUL. Tribunal de Justiça do Rio Grande do Sul. Pesquisa sobre transfusão de sangue e testemunha de Jeová. Disponível em: <http://www.tjrs.jus.br/busca/search?q=testemunha+de+jeov\%C3\%A1+transfus\%C3\%A3o+de+sangue\&proxystylesheet=tjrs_index\&clien$\mathrm{t}=\mathrm{tjrs} \_$index\&filter $=0 \&$ getfield $s={ }^{*} \& \mathrm{aba}=$ juris\&entsp $=\mathrm{a} \_-$politica-site\&wc $=200 \& w c \_m c=1 \& 0-$ $\mathrm{e}=U T \mathrm{TF}-8 \& \mathrm{ie}=\mathrm{UTF}-8 \& \mathrm{ud}=1 \& \mathrm{lr}=$ lang_pt\&sort=date\%3AD\%3AS\%3Ad1\&as_qj=testemunha+de+jeov\%C3\%A1\&site=ementario\&as_epq=\&as_oq=\&as_eq=\&as_q=+\#main_res_juris $>$. Acesso em: 31 out. 2015.

RIO GRANDE DO SUL. Tribunal de Justiça do Rio Grande do Sul. Décima Segunda Câmara Cível. Agravo de Instrumento no 70032799041. Relator: Cláudio Baldino Maciel. Data de Julgamento: 06/05/2010. Data de Publicação: DJe 03/08/2010.

RIO GRANDE DO SUL. Tribunal de Justiça do Rio Grande do Sul. Quinta Câmara Cível. Apelação Cível no 70020868162. Relator: Umberto Guaspari Sudbrack. Data de Julgamento: 22/08/2007. Data de Publicação: DJe 22/08/2007. 
SOARES, Luís. Leia a íntegra do voto histórico que determina a retirada de crucifixos em tribunais no RS. Disponível em: <http://www.pragmatismopolitico.com.br/2012/03/leia-a-integra-do-voto-historico-que-determina-a-retirada-de-crucifixos-em-tribunais-no-rs.html>. Acesso em: 28 ago. 2015.

TURCI, Érica. Reino de Espanha: o primeiro império global da era moderna. UOL Educação, São Paulo, 5 abr. 2010. Disponível em: <http://educacao.uol.com.br/disciplinas/historia/reinode-espanha-o-primeiro-imperio-global-da-era-moderna.htm>. Acesso em: 21 set. 2015. ZANONE, Valério. Laicismo. In: BOBBIO, Norberto; MATEUCCI, Nicola; PASQUINO, Gianfranco (org.). Dicionário de Política. Tradução de Carmen C. Varriele. 5 ed. Brasília: Universidade de Brasília, 1998. 